\title{
PENGEMBANGAN PROGRAM USAHA EKONOMIS PRODUKTIF DALAM PEMBERDAYAAN PEREMPUAN DI KABUPATEN SUMENEP
}

\author{
Dwi Listia Rika Tini \\ Fakultas Ilmu Sosial dan Ilmu Politik, Universitas Wiraraja \\ email: rikatini@wiraraja.ac.id
}

\begin{abstract}
This study aims to explain the Development of Productive Economic Business Programs in Sumenep Regency in the context of empowering women and improving the quality of women as development resources. The Development of Productive Economic Business Program is an effort of Sumenep Regency in order to build a better economy going forward related to the village economy. The method used in this study is a qualitative analysis method in which references are the basis for analysis. The Productive Economic Business Program Policy in Sumenep Regency is implemented under the auspices of the Community and Women's Empowerment Agency (BPMP) in the form of craftsmen business groups that utilize Natural Resources and Human Resources in each Village. This phase of UEP development activities is carried out through an empowerment process carried out over a period of 3 (three) years and the phasing plans are 1) First Year (2013), namely the Growth Stage; 2) Second Year (2014) Development Phase and 3) Third Year (2015) Independence Phase. From the UEP development activities that have a positive impact on women in rural areas, they can make money and help husbands without having to work far outside the home.
\end{abstract}

Keyword: development; UEP; women's empowerment.

\begin{abstract}
ABSTRAK
Penelitian ini bertujuan untuk menjelaskan Pengembangan Program Usaha Ekonomis Produktif di Kabupaten Sumenep dalam rangka pemberdayaan perempuan dan peningkatan kualitas perempuan sebagai sumberdaya pembangunan. Pengembangan Program Usaha Ekonomis Produktif merupakan upaya Kabupaten Sumenep dalam rangka membangun ekonomi yang lebih baik ke depan yang berkaitan dengan ekonomi desa. Metode yang digunakan dalam penelitian ini metode analisis kualitatif dimana acuan pustaka sebagai basis untuk analisis. Kebijakan Program Usaha Ekonomi Produktif di Kabupaten Sumenep dilaksanakan di bawah naungan Badan Pemberdayaan Masyarakat Dan Perempuan (BPMP) berupa kelompok-kelompok usaha pengrajin yang memanfaatkan Sumber Daya Alam dan SDM yang ada di setiap Desa. Tahap kegiatan pengembangan UEP ini dilaksanakan melalui proses pemberdayaan yang dilakukan selama kurun waktu 3 (tiga) tahun dan rencana pentahapannya adalah 1) Tahun Pertama (Tahun 2013) yaitu Tahap Penumbuhan; 2) Tahun Kedua (Tahun 2014)Tahap Pengembangan dan 3) Tahun Ketiga (Tahun 2015) Tahap Kemandirian. Dari kegiatan pengembangan UEP tersebut memberikan dampak positif terhadap perempuan-perempuan yang ada di pedesaan, mereka dapat menghasilkan uang dan membantu para suami tanpa harus bekerja jauh diluar rumah.
\end{abstract}

Kata Kunci: pengembangan; UEP; pemberdayaan perempuan. 


\section{PENDAHULUAN}

Hasil Susenas 2010 menunjukkan bahwa secara nasional jumlah penduduk Indonesia tahun 2010 sebesar 237,5 juta jiwa, jumlah penduduk laki-laki lebih banyak dibandingkan perempuan. Persentase penduduk laki-laki sebesar 50,17 persen, sedangkan perempuan sebesar 49,83 persen. Berdasarkan daerah tempat tinggal, di perkotaan lebih banyak penduduk perempuan (50,02 persen) sedangkan di perdesaan lebih banyak penduduk lakilaki (50,37 persen), dari jumlah penduduk tersebut penduduk miskin 13,33 $\%, 2 / 3$ nya ada di perdesaan. Jumlah penduduk hamper miskin berjumlah sekitar 24 juta. Walaupun jumlahnya seimbang, namun kualitas hidup perempuan masih lebih rendah daripada kaum laki-laki.

Potensi kuantitatif dari SDM perempuan Dilihat menurut jenis kelamin, komposisi penduduk produktif ternyata lebih banyak penduduk perempuannya dibandingkan lakilaki, yaitu 66,11 persen berbanding 65,36 persen. Walaupun jumlahnya seimbang, namun kualitas hidup perempuan masih lebih rendah daripada kaum laki-laki. Potensi kuantitatif dari SDM perempuan Indonesia ini sayangnya belum diimbangi dengan potensi kualitatif secara seimbang. Dengan kata lain, walaupun saat ini cukup banyak perempuan Indonesia yang menunjukkan bahwa dirinya mampu bersaing sekaligus memberikan kontribusi yang tidak kalah besarnya dalam berbagai bidang pembangunan, mulai dari ilmu pengetahuan, teknologi, politik, ekonomi, sosial, dan bahkan pertahanan dan keamanan, namun masih lebih banyak lagi perempuan Indonesia yang belum mampu menunjukkan potensi dan jati dirinya secara optimal, karena masih terkungkung oleh keterbatasan/kemiskinan secara struktural, kultural, dan alamiah. Rendahnya kualitas hidup perempuan akan mempengaruhi Indeks Pembangunan Manusia Indonesia secara keseluruhan, terutama di bidang-bidang strategis seperti pendidikan, kesehatan dan ekonomi, yang pada akhirnya akan berdampak negatif terhadap proses pembangunan bangsa yang sedang kita lakukan.

Bukan hanya di lingkup nasional saja di lingkup lokal peran perempuan dalam dunia kerja sangat kecil. Seperti halnya di Kabupaten Sumenep ditunjukkan dengan rendahnya peran serta perempuan dalam usaha-usaha formal. Sebagian besar perempuan masih berkiprah di sektor informal dan pekerjaan yang tidak menggunakan peralatan dan teknologi yang canggih. Pekerjaan ini biasanya kurang memberikan jaminan perlindungan sosial dan perlindungan secara hukum dan jaminan kesejahteraan yang memadai, di samping kondisi kerja yang kurang sehat dan tentu saja dengan tingkat pendapatan yang rendah. Misalnya saja dalam bidang Usaha Mikro, kontribusi masyarakat perempuan sangat bermakna bagi perkembangan perekonomian nasional. Lebih dari 30 juta pengusaha mikro, kecil danmenengah, 60 persennya adalah perempuan. Namun kondisi saat ini perempuan pengusaha mikro dan kecil masih belum menggembirakan. Kendala terbesar yang dihadapi oleh perempuan pengusaha mikro, kecil dan menengah pada umumnya pada aspek pemasaran, permodalan, sumber daya manusia dan teknologi serta rendahnya penguasaan perempuan terhadap aset produksi. Disamping itu kebutuhan yang sangat diperlukan bagi perempuan pengusaha mikro dan kecil adalah berupa pendampingan oleh lembaga yang dekat dengan pengusaha (perempuan) dalam memberikan layanan pengembangan usaha yang cepat, mudah serta dirasakan hasil secara cepat.

Maka dari itu untuk meminimalisir hal diatas Kabupaten Sumenep membuat sebuah Pengembangan Program Usaha Ekonomis Produktif untuk kaum perempuan. Dengan terbentuknya pengembangan program usaha ekonomis produktif di Kabupaten Sumenep dalam rangka pemberdayaan perempuan dan peningkatan kualitas perempuan sebagai sumberdaya pembangunan. Pengembangan Usaha Ekonomis Produktif merupakan 
upaya Kabupaten Sumenep dalam rangka membangun ekonomi yang lebih baik ke depan yang berkaitan dengan ekonomi desa atau kelurahan. Program ini akan dilaksanakan oleh beberapa desa di Kabupaten Sumenep yang mempunyai nilai SDA dan SDM yang tinggi. Kebijakan program Usaha Ekonomi Produktif di Kabupaten Sumenep dilaksanakan di bawah naungan Badan Pemberdayaan Masyarakat Dan Perempuan (BPMP) berupa kelompok-kelompok Usaha pengrajin yang memanfaatkan Sumber Daya Alam dan SDM yang ada di setiap Desa.

Alasan pokok pentingnya melakukan pengembangan usaha ekonomi di perdesaan, yaitu: a). Masih adanya masyarakat perempuan yang memiliki kemampuan rendah dalam mengakses usaha yang disebabkan oleh keterbatasan penguasaan sumberdaya alam, sehingga kurang mempunyai peluang dalam berusaha di bidang ekonomi maupun pertanian; b). masih adanya kemiskinan struktural, sehingga meskipun telah berusaha tetapi pendapatan yang diperoleh belum memenuhi kebutuhan keluarga. c) masih terbatasnya pengetahuan tentang pemberdayaan perempuan; e) belum optimalnya fungsi kelembagaan aparat dan masyarakat; f) masih terbatasnya akses kaum perempuan terhadap lembaga permodalan, lembaga pemasaran, informasi dan teknologi; g) rendahnya tingkat pendidikan perempuan; h) terbatasnya lapangan pekerjaan untuk kaum perempuan. Hal ini dapat mendorong terjadinya kerawanan pangan dan kemiskinan upaya untuk mengatasi permasalahan tersebut adalah melalui Pengembangan Usaha Ekonomi Produktif.

\section{METODE}

Penelitian ini menggunakan metode analisis kualitatif dimana acuan pustaka sebagai basis untuk analisis yaitu mengumpulkan data, informasi, dengan menelaah jurnaljurnal penelitian, buku-buku referensi, literatur- literatur, serta sumber-sumber terpercaya baik tulisan maupun digital yang berhubungan dan relevan dengan topic penulisan.

\section{HASIL DAN PEMBAHASAN}

\section{Konseptualisasi}

Pengembangan Program Usaha Ekonomis Produktif adalah program yang di rumuskan oleh pemerintah Kabupaten Sumenep untuk memberdayakan perempuan khususnya di pedesaan. Program ini adalah bentuk implementasi dari intruksi Presiden No. 9 tahun 2000 tentang Pengarusutamaan Gender (PUG) dalam Pembangunan nasional, sebagai salah satu strategi untuk mewujudkan keadilan dan kesetaraan gender. Pengembangan Program Usaha Ekonomis Produktif yang dilaksanakan di Kabupaten Sumenep di bawah naungan Badan Pemberdayaan Masyarakat Dan Perempuan (BPMP) berupa kelompok-kelompok Usaha. Program ini bertujuan untuk meningkatkan perekonomian keluarga agar bisa hidup berkecukupan dan dapat meringankan beban dari suami. Program UEP di Kabupaten Sumenep ini memfocuskan Usaha Ekonomis Produktifnya pada pengrajin yang ada di setiap Desa dengan memanfaatkan sumber daya alam yang ada dan SDM. Tujuan dan Sasaran UEP, meliputi:

a. Tujuan Program Usaha Ekonomis Produktif

1) Tujuan Umum

Program ini bertujuan untuk memberdayakan masyarakat khususnya perempuan untuk meningkatkan perekonomian keluarga agar bisa hidup berkecukupan dan dapat meringankan beban dari suami 
2) Tujuan Khusus

$>$ Untuk membantu Penghasilan Keluarga.

$>$ Melatih kaum perempuan dalam hal membuat usaha yang bisa memberikan keuntungan.

> Memberikan pandangan kepada masyarakat bahwa bukan hanya laki-laki saja yang bisa bekerja untuk mensejahterakan keluarga (berkaitan dengan kesetaraan Gender).

$>$ Menciptakan lapangan kerja bagi keluarga miskin.

b. Sasaran Program Usaha Ekonomis Produktif.

Sesuai dengan tujuan tersebut di atas, sasaran UEP adalah sebagai berikut:

1) Teridentifikasinya karakteristik personal (SDM), kehidupan, dan aktivitas ekonomi perempuan miskin di kabupaten Sumenep di perdesaan.

2) Terbentuknya Kelompok Perempuan Produktif sebagai wadah pemberdayaan, peningkatan kemandirian, dan peningkatan kondisi sosial-ekonomi kaum perempuan miskin.

3) Tumbuh dan berkembangnya kegiatan ekonomi produktif yang dikelola oleh Kelompok Perempuan Produktif.

Sedangkan struktur Implementasi Program UEP yang di lakukan oleh Kabupaten Sumenep memberikan tanggung jawab kepada:

a. Pihak BPMP (Badan Pemberdayaan Masyarakat dan Perempuan) Sub Bidang Pemberdayaan Perempuan.

b. Ibu Camat dan Ibu Kepala Desa selaku pendamping.

c. Ketua kelompok d tiap usaha tersebut.

Seperti pada gambar dibawah ini:

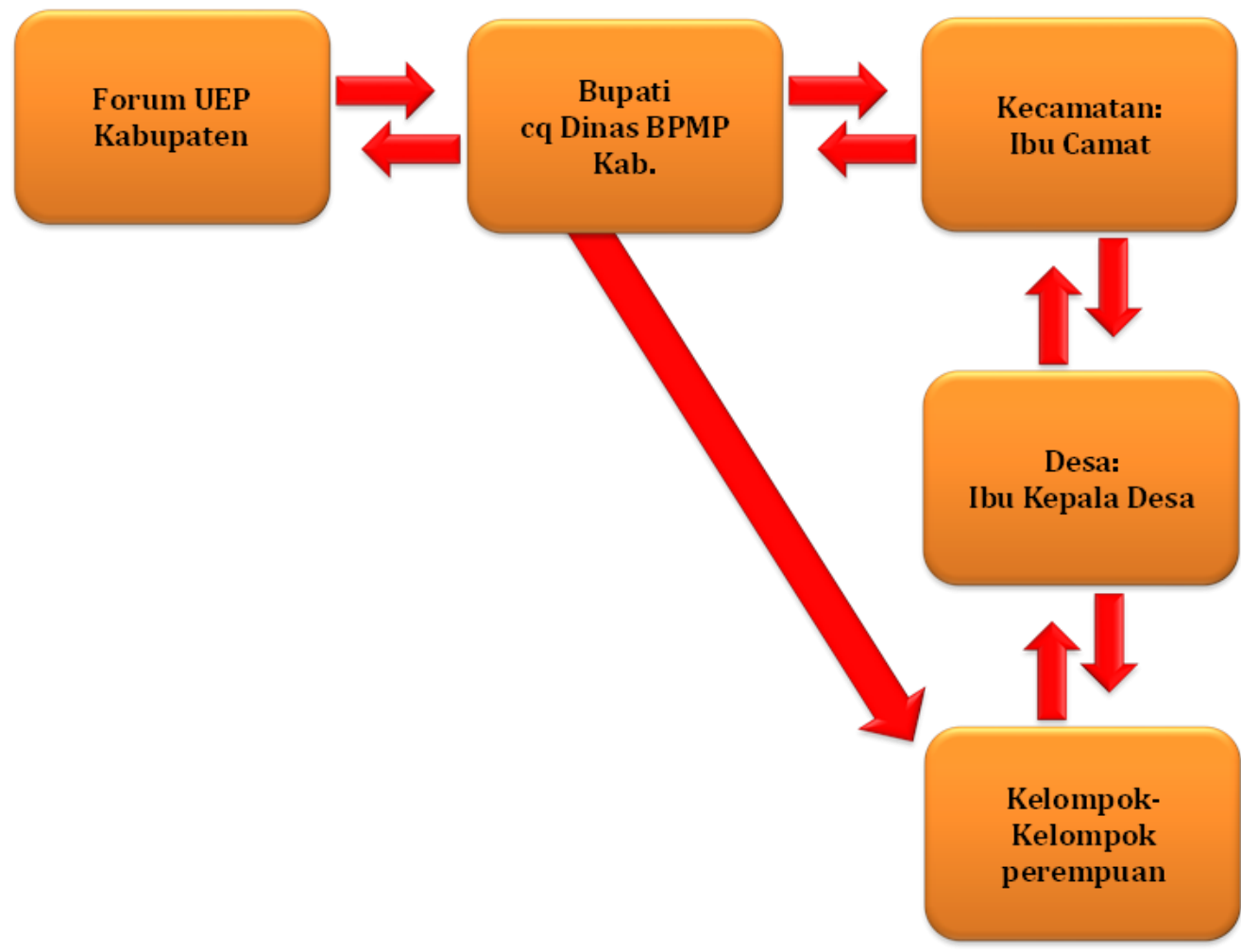

Gambar 1. Implementasi Program Usaha Ekonomis Produktif

(Sumber: Data Primer BPMP Bidang Pemberdayaan Perempuan Tahun 2013) 
Dari gambar di atas sudah bisa dilihat dengan cara bagaimana tanggung jawab itu dilaksanakan, awalnya mengadakan sebuah fórum untuk membahas siapa saja yang terlibat dalam program ini, selanjutnya Bupati memberikan tanggung jawab kepada pihak BPMP, sub bidang pemberdayaan perempuan selaku pelaksana dan pengawas dalam program ini yang bertugas untuk melakukan pengawasan kepada tiap desa yang melaksanakan program tersebut minimal 1bulan sekali, BPMP itu sendirinya memberikan tanggung jawab kepada ibu camat dan ibu kepala desa selaku pendamping dalam pelaksanaan program tersebut, setiap seminggu sekali para pendamping harus ke desa untuk melakukan pendampingan dan mengarahkan kepada kaum perempuan tentang usahanya tersebut. Ibu camat dan ibu kepala desa harus selalu berkoordinasi secara rutin untuk membahas program tersebut agar berjalan dengan lancar. Selain itu pihak dari BPMP juga melakukan koordinasi kepada Ibu Camat untuk memberikan panduan secara langsung. Karena ibu kepala desa pihak yang terdekat dengan masyarakat desa khususnya kaum perempuan yang diwakilkan oleh ketua kelompok juga berkoordinasi dengan ibu kepala desa untuk memberikan informasi perkembangan baik dalam hal modal dan pemasaran.

Kegiatan Pengembangan Program UEP ini dilaksanakan melalui proses pemberdayaan yang dilakukan selama kurun waktu 3 (tiga) tahun dan rencana pentahapannya adalah 1) Tahun Pertama (Tahun 2013) yaitu Tahap Penumbuhan; 2) Tahun Kedua (Tahun 2014) Tahap Pengembangan dan 3) Tahun Ketiga (Tahun 2015) Tahap Kemandirian, dengan tahapan kegiatan seperti dibawah ini:

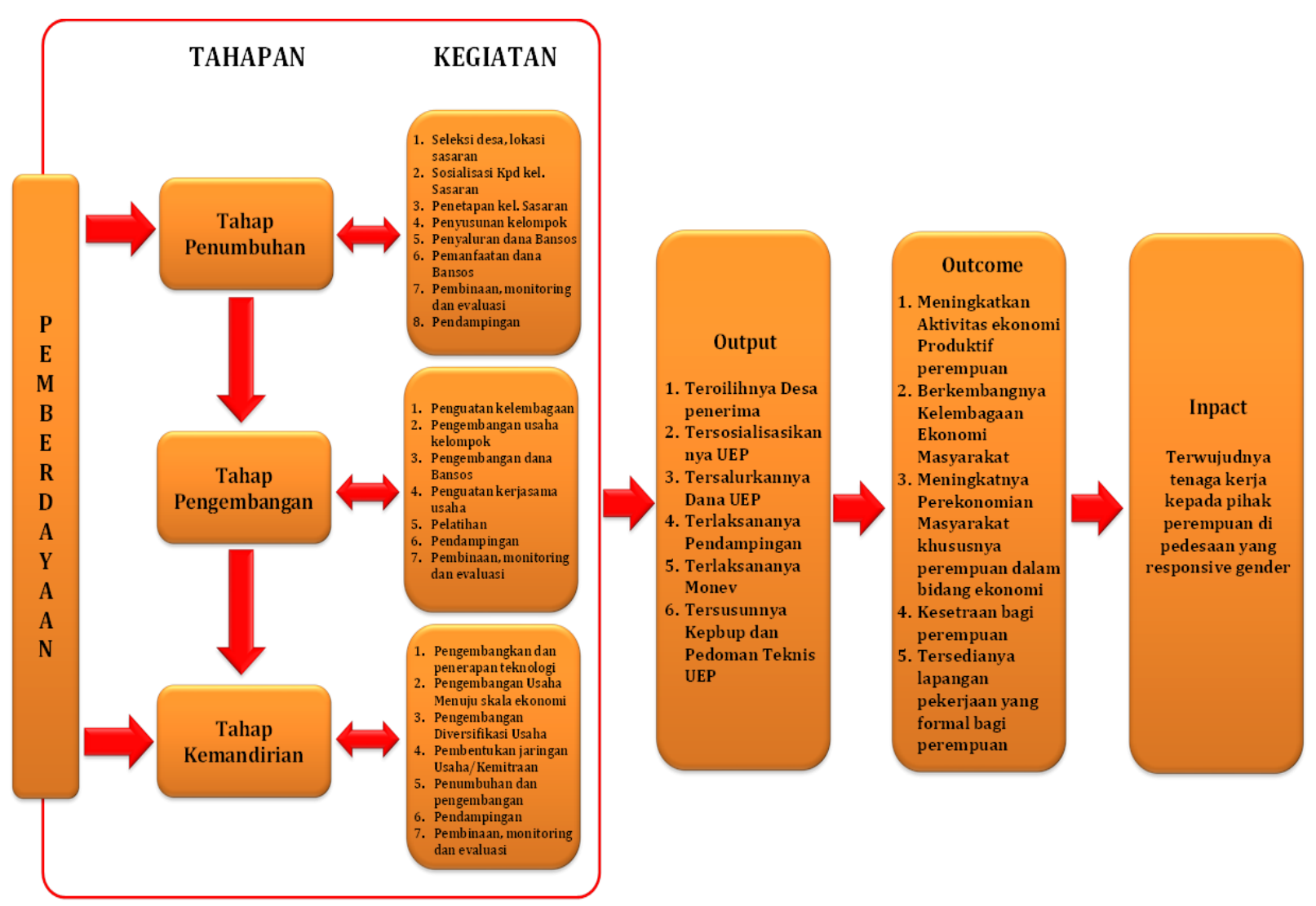

Gambar 2. Pelaksanaan Program UEP BPMP

(Sumber: Buku Panduan Pelaksanaan UEP BPMP Bidang Pemberdayaan Perempuan tahun 2013-2015) 
a. Tahap Penumbuhan

Dilaksanakan pada tahun pertama dalam waktu satu tahun dan melibatkan unsurunsur kelembagaan perdesaan dan stakeholder terkait. Tahap persiapan terdiri dari kegiatan-kegiatan sebagai berikut:

1) Seleksi desa, lokasi dan kelompok sasaran

2) Sosialisasi Kepada Kelompok Sasaran

3) Penetapan Kelompok Sasaran

4) Penyusunan Rencana Usaha Kelompok (RUK)

5) Penyaluran dana Bansos

6) Pemanfaatan dana Bansos

7) Pembinaan, monitoring dan evaluasi.

8) Pendampingan

b. Tahap Pengembangan

Tahap pengembangan ini dilaksanakan pada tahun kedua dalam kurun waktu satu tahun. Pengembangan dan penguatan kelembagaan dilakukan dengan memperkuat organisasi/kelembagaan sesuai dengan peran dan fungsinya serta pembenahan prosedur administrasi baku yang dapat dipertanggungjawabkan. Langkah-langkah yang dilakukan antara lain:

1) Penguatan kelembagaan;

2) Pengembangan usaha kelompok;

3) Pengembangan Dana Bansos;

4) Pelatihan teknis dan manajemen pengelolaan keuangan;

5) Penguatan kerjasama usaha;

6) Pendampingan;

7) Pembinaan, monitoring dan evaluasi.

c. Tahap Kemandirian

Tahap Kemandirian ini dilaksanakan pada tahun ketiga dalam kurun waktu satu tahun. Arah kemandirian dalam rangka optimalisasi peran kelembagaan perdesaan dilakukan melalui pengembangan kapasitas kelembaga sesuai perkembangan dan peluang yang ada, seperti:

1) Pengembangan dan penerapan teknologi untuk perbaikan produksi (kualitas, kuantitas, dan kontinyuitas);

2) Pengembangan usaha menuju skala ekonomi yang mampu memberikan pendapatan layak dan berkesinambungan;

3) Pengembangan diversifikasi usaha untuk meningkatkan pendapatan;

4) Pembentukan jaringan usaha/kemitraan;

5) Penumbuhan dan Pengembang Lembaga Keuangan Mikro;

6) Pengurangan peran pendampingan;

7) Pembinaan, monitoring dan evaluasi.

2. Prinsip-Prinsip Hukum dalam Pengembangan Program Usaha Ekonomis Produktif

Dalam GBHN 1999-2004 menetapkan dua arah kebijakan pemberdayaan perempuan yakni pertama meningkatkan kedudukan dan peranan perempuan dalam kehidupan berbangsa dan bernegara melalui kebijakan nasional yang diemban oleh lembaga yang mampu memperjuangkan terwujudnya kesetaraan dan keadilan gender. Kedua meningkatkan kualitas peran dan kemandirian organisasi perempuan dengan tetap mempertahankan nilai persatuan dan kesatuan serta nilai historis perjuangan perempuan dalam rangka melanjutkan usaha pemberdayaan perempuan serta 
kesejahteraan keluarga dan masyarakat. Dengan demikian pemberdayaan perempuan dalam rangka mewujudkan KKG (Kesetaraan dan Keadilan Gender) merupakan komitmen bangsa Indonesia yang pelaksanaannya menjadi tanggung jawab seluruh pihak eksekutif, legislatif, yudikatif, tokoh-tokoh agama dan masyarakat secara keseluruhan. Sesuai dengan dua arahan kebijakan itu, pemerintah bertanggung jawab untuk merumuskan kebijakan-kebijakan pemberdayaan perempuan di tingkat nasional maupun daerah, yang pelaksanaannya dapat memberikan hasil terwujudnya kesetaraan dan keadilan gender di segala bidang kehidupan dan pembangunan.

Selanjutnya dalam Rencana Strategi Kementerian Pemberdayaan Perempuan 2001-2004, program yang disusun terdiri dari program dalam rangka pembangunan pemberdayaan perempuan, peningkatan kesejahteraan dan perlindungan anak dan upaya peningkatan kemampuan. Mencakup Program Pengembangan dan Keserasian Kebijakan Pemberdayaan Perempuan, Program Peningkatan Kualitas Hidup Perempuan, Program Peningkatan Peran Masyarakat kemampuan Kelembagaan Pengarusutamaan Gender; Program Peningkatan Kesejahteraan dan Perlindungan Anak; Program Sumber Daya, Sarana dan Prasarana. Mengingat produk tersebut merupakan undang-undang, maka untuk mewujudkan kesetaran dan keadilan gender harus menjadi komitmen bersama. Dalam rangka mewujudkan kesetaraan dan keadilan gender melaui program yang peka akan permasalahan gender, Kementerian Pemberdayaan Perempuan telah bekerjasama dengan UNFPA dalam melaksanakan serangkaian kegiatan Mainstreaming Gender Issues in Reproductive Health and Population Policies and Programmes.

Kesetaraan dan Keadilan Gender (KKG) sudah menjadi isu yang sangat penting dan sudah menjadi komitmen bangsa-bangsa di dunia termasuk Indonesia sehingga seluruh negara menjadi terikat dan harus melaksanakan komitmen tersebut. Upaya mewujudkan Kesetaraan dan Keadilan Gender (KKG), di Indonesia dituangkan dalam kebijakan nasional sebagaimana ditetapkan dalam UU No. 25 th. 2000 tentang Program Pembangunan Nasional-PROPENAS 2000-2004, dan dipertegas dalam intruksi Presiden No. 9 tahun 2000 tentang Pengarusutamaan Gender (PUG) dalam Pembangunan nasional, sebagai salah satu strategi untuk mewujudkan keadilan dan kesetaraan gender dan diperkuat juga dengan Peraturan Gubernur Jawa Timur Nomor 27 Tahun 2010 Tentang Pedoman Pelaksanaan Pengarusutamaan Gender Dalam Pembangunan Provinsi Jawa Timur, sebagaimana pasal 2 ayat 3 adalah bertujuan untuk memberikan pedoman bagi aparatur Pemerintah Provinsi, Kabupaten/Kota dalam menyusun strategi pengintegrasian gender dalam kegiatan pembangunan daerah.

Berangkat dari kebijakan dan peraturan tersebut Kabupaten Sumenep membuat kebijakan pemberdayaan perempuan dengan program usaha ekonomis produktif. Kebijakan program Usaha Ekonomi Produktif yang di Kabupaten Sumenep dilaksanakan di bawah naungan Badan Pemberdayaan Masyarakat Dan Perempuan (BPMP). Dengan dasar tersebut dikeluarkan Surat Keputusan Bupati dibawah naungan Badan Pemberdayaan Masyarakat dan Perempuan Kabupaten Sumenep Nomor: 188.4/57a/436.44/2013 tentang penetapan tim panitia dan pendamping pengembangan usaha ekonomis produktif sebagai dasar hukum terealisasinya Pengembangan Program Usaha Ekonomis Produktif. 


\section{Evaluasi Pengembangan Program Usaha Ekonomis Produktif}

Salah satu aspek yang sangat penting dalam pelaksanaan kegiatan adalah Evaluasi. Evaluasi bukanlah suatu kegiatan khusus, tetapi dilaksanakan secara mendalam pada semua tahap kegiatan UEP agar setiap proses berjalan dengan baik dan tujuannya untuk memberdayakan perempuan akan tercapai. Dalam evaluasi program UEP ini menggunakan Social Audit yaitu dilaksanakan oleh semua pihak yang terlibat dalam kegiatan di mana intinya adalah peran masyarakat sebagai pelaku utama.

Evaluasi dimaksudkan untuk mengetahui perkembangan pelaksanaan kegiatan dan mendeteksi secara dini permasalahan yang muncul di lapangan sehingga upaya penyelesaian dapat segera dilaksanakan. Untuk itu pelaksanaan evaluasi harus dilakukan secara berkala, tepat waktu dan berjenjang dari tingkat kelompok/desa, kecamatan, dan kabupaten/kota. Untuk mengetahui perkembangan dan tingkat keberhasilan kegiatan UEP dapat dilihat dari hasil capaian masing-masing indikator.

Evaluasi dilakukan secara berjenjang dari tingkat kelompok/desa, kecamatan, dan kabupaten/kota, secara berkala, berkelanjutan dan tepat waktu. Kelompok/Desa melaporkan pada kecamatan, kabupaten/kota tentang situasi dan perkembangan pelaksanaan UEP dikelompok/desa dengan formulir yang telah disepakati. Kecamatan berfungsi sebagai pemantau, pendamping dan sekaligus penghubung ke kabupaten/kota dan menyampaikan upaya-upaya yang telah dilakukan oleh kecamatan serta meneruskan hal-hal yang tidak dapat dilakukan oleh kecamatan dengan menggunakan form yang telah disepakati.

a. Tim Teknis Kecamatan

Kecamatan memantau kegiatan lapangan secara berkala dan mengevaluasi hasil pemantauan serta laporan kelompok/desa dan selanjutnya melaporkan ke kabupaten sesuai dengan format yang disepakati. Kecamatan memberikan feedback kepada kelompok/desa melakukan follow up terhadap kondisi yang memerlukan penanganan segera atau dikoordinasikan oleh pengelola program tingkat kabupaten/kota.

b. Tim Teknis Kabupaten

Kabupaten memantau kegiatan lapangan secara berkala dan mengevaluasi hasil pemantauan dan melaporkan ke Bupati sesuai dengan format yang disepakati. Selanjutnya kabupaten memberikan feedback kepada kecamatan terhadap kegiatan yang memerlukan penanganan segera atau dikoordinasikan oleh pengelola program tingkat kabupaten

Evaluasi harus dilakukan baik oleh Tim Teknis Kabupaten maupun Tim Teknis Kecamatan secara berjenjang, berkala, tepat waktu, sehingga dapat diambil suatu tindakan korektif sesuai dengan perencanaan dan tujuan yang telah ditetapkan. Selain Evaluasi hal yang penting untuk dilakukan agar tujuan untuk memberikan kesetaraan yang responsive gender melalui program usaha ekonomis produktif yaitu Pelaporan.

Pelaporan pelaksanaan kegiatan Pengembangan Usaha Ekonomi Produktif untuk kaum perempuan di tingkat desa, dilakukan secara periodik dan berkesinambungan dengan ketentuan sebagai berikut:

a. Kelompok perempuan penerima bantuan sosial Pengembangan Usaha Ekonomi Produktif wajib melaporkan penggunaan dan perkembangan usaha kelompoknya secara periodik kepada Badan Pemberdayaan Masyarakat dan Perempuan (BPMP) di Kabupaten setiap 1 bulan sekali secara berkesinambungan. 
b. Laporan dari masing-masing ketua kelompok perempuan penerima bantuan, direkap dan dianalisa oleh Badan Pemberdayaan Masyarakat dan Perempuan di Kabupaten yang selanjutnya dilaporakan kepada Bupati

\section{KESIMPULAN}

Pengembangan Usaha Ekonomis Produktif yang dilaksanakan di Kabupaten Sumenep di bawah naungan Badan Pemberdayaan Masyarakat Dan Perempuan (BPMP) berupa kelompok-kelompok Usaha. Program ini bertujuan untuk meningkatkan perekonomian keluarga agar bisa hidup berkecukupan dan dapat meringankan beban dari suami. Program UEP di Kabupaten Sumenep ini memfocuskan Usaha Ekonomis Produktifnya pada pengrajin yang ada di setiap Desa dengan memanfaatkan sumber daya alam yang ada.

Tahap kegiatan pengembangan UEP ini dilaksanakan melalui proses pemberdayaan yang dilakukan selama kurun waktu 3 (tiga) tahun dan rencana pentahapannya adalah A) Tahun Pertama (Tahun 2013) yaitu Tahap Penumbuhan; B) Tahun Kedua (Tahun 2014)Tahap Pengembangan dan C) Tahun Ketiga (Tahun 2015) Tahap Kemandirian. Dari kegiatan yang dijalankan di Kabupaten Sumenep memberikan dampak positif terhadap perempuan-perempuan yang ada di pedesaan, mereka dapat menghasilkan uang dan membantu para suami tanpa harus bekerja jauh diluar rumah.

Salah satu aspek yang sangat penting dalam pelaksanaan kegiatan tersebut adalah Evaluasi. Evaluasi yang dimaksud dilakukan oleh Tim Teknis Kabupaten maupun Tim Teknis Kecamatan secara berjenjang, berkala, tepat waktu, sehingga program usaha ekonomis produktif yang dilakukan sesuai dengan tujuan awal dari program tersebut yaitu kesetaraan yang responsive gender.

\section{DAFTAR RUJUKAN}

Ali Ridho. 2009. Bias Gender Dalam Tes. Malang: UIN-Malang Press

Mansour Fakih. 2001. Analisis Gender dan Transformasi Sosial. Pustaka Pelajar. Yogyakarta

Buku panduan dan tujuan program usaha Ekonomis Produktif di Sub Badan Pemberdayaan Perempuan.

Data Primer Badan Pemberdayaan Masyarakat dan Perempuan Tahun Buku 2013

Kementrian Negara pemberdayaan Perempuan, Modul Fasilitasi Pelatihan Pengarusutamaan Gender Bagi Fasilitator kategori Pengembangan, Jakarta: Kementrian Negara Pemberdayaan Perempuan, 2006

Sri Sundari Sasongko, Isu Gender Modul 1, (BkkbN,2007,6) dalam Skripsi Muhammad Ihsan Armia. 2011. Kawin Paksa dalam Perspektif Fiqh dan Gender. UIN Malang

Sri Sundari Sasongko, Modul 2 Konsep dan Teori Gender. BKKBN,2007

https://www.Ny Nina Soekarwo.htm, Lensa Diskopjatim. 2010.

https://www.Pemerintah Kota Malang _ Berita Malang _ PROGRAM PEMBERDAYAAN PEREMPUAN PENGEMBANG EKONOMI LOKAL.htm.

https://www.USAHA EKONOMI PRODUKTIF (UEP) SUMENEP.htm, USAHA EKONOMIS PRODUKTIF SUMENEP. 2010.

www.bps.com. Perkembangan Data Usaha Mikro, Kecil, Menengah (UMKM) dan Usaha Besar (UB) tahun 2008-2009

www.smecda.com/01/Koperasi_dan_Pemberdaya_peremp_3.pdf, 